\title{
ÖTANAZİ: YAŞAMA HAKKI AÇISINDAN BİR DEĞERLENDIRME
}

Euthanasia: An Evaluation with Reference to the 'Right to Life'

\section{Ertuğrul Cenk GÜRCAN*}

\section{ÖZET}

$\mathrm{Bu}$ makalede, 'yaşama hakkı' açısından aktif ötanazi tartışılmaktadır. Aktif ötanaziyi bir 'insan hakkı' olarak tanımlamak, hem hak kavramının ayrılmaz bir parçası olan ödev unsuru açısından, hem de temel bir insan hakkı olan yaşama hakkının vazgeçilmezliği açısından önemli kavramsal ve kuramsal zorluklara yol açmaktadır. Aktif ötanazi, kavramın tanımı gereği, kişinin öldürülmesi talebinin fiilen karşılanmasını gerektirmektedir; ama bütün doktorların bu talebi reddetme hakkına sahip oldukları düşünüldüğünde, ötanazi talep eden kimsenin talebinin bağlayıcı olmadığı görülmekte, dolayısıyla bu tür bir talebin 'hak'kın ödev unsurunu içermediği ortaya çıkmaktadır. Kişinin yaşama hakkına başkası tarafından son verilmesine yol açan aktif ötanazi, yaşama hakkının vazgeçilmezliği açısından da sorun doğurmaktadır.

*Siyaset Bilimi Uzmanı (ecgurcan@gmail.com). 
Anahtar Sözcükler: Ötanazi, Aktif ötanazi, Hak, İnsan hakları, Yaşama hakkının vazgeçilmezliği

\begin{abstract}
This article discusses active euthanasia with reference to the 'right to life'. To define active euthanasia as a 'human right' gives rise to serious conceptual and theoretical difficulties because of the 'duty' element which is a constituent of the 'rights' concept, but also because of the inalienability of the 'right to life.' Active euthanasia, by definition, implies that the request to be allowed to die should be met, but if we recognize that all doctors have the right to refuse this request, we realize that this request does not have a binding effect, thus does not contain the 'duty' element. Moreover, when we consider the inalienability of the 'right to life,' active euthanasia gives rise to similar serious difficulties.
\end{abstract}

Keywords: Euthanasia, Active euthanasia, Right, Human rights, Alienability of the right to life

\title{
Giriş
}

İnsan hakları literatüründe özellikle 20. yüzyılın ikinci yarısından itibaren gündeme gelen 'ötanazi'nin ${ }^{1}$ hak kavramı ve kuramı açısından nasıl değerlendirilebileceği tartışmalı bir konudur. ${ }^{2}$ Zira hak kavramı ve kuramı açısından bakıldığında, ötanazinin çok yönlü ve çeşitli tartışmaları gerektiren bir niteliğe ve karmaşıklığa sahip olduğu görülmektedir. $\mathrm{Bu}$

${ }^{1}$ Türkçe literatürde 'ötenazi’, ‘ötanezi’, ‘ötanazi’ gibi farklı şekillerde yazılmakla birlikte, bu çalışmada Türk Dil Kurumu'nun (2005) sözlüğünde yazıldığı gibi, yani 'ötanazi' şeklinde yazılacaktır.

2 Burada kullanılan 'ötanazi' deyişiyle, 'acısız ani ölüm (talebi)' kastedilmektedir. 'Ötanazi’ kavramının tanımına, niteliğine ve kapsamına ilişkin bazı meseleler izleyen sayfalarda ortaya konulacaktır. Ancak burada mutlaka dikkat edilmesi gereken husus, literatürde, 'ötanazi' deyişinin zaman zaman bir 'hak' anlamı içerecek şekilde kullanılabilmesi ya da anlaşılabilmesidir. Bunun ne gibi sorunlara yol açabildiği çalışmanın izleyen kısımlarında tartışılmaktadır. 
çalışmada, literatürde uzunca bir süredir tartışılmakta olan ötanazi meselesi, hak kavramı ve kuramında kabul gören belli argümanlar açısından ele alınacak ve değerlendirilecektir.

Ötanazi, hem felsefi hem de hukuki olarak çeşitli açılardan değerlendirilebilir. Bu kadar kapsamlı bir konunun kısa bir makalede her yönüyle ve ayrıntılı bir şekilde incelenmesi elbette mümkün değildir. Dolayısıyla, bu çalışmada, ötanazi meselesi sadece hak kavramı ve kuramı açısından incelenecektir. Bununla birlikte, hak kavramı ve kuramı da birçok argüman ve karşı argüman içeren tartışmalardan oluşmaktadır; bu nedenle, bu açıdan da belli bir sınırlama yapmak kaçınılmaz gözükmektedir. $\mathrm{Bu}$ bağlamda, çalışmada, ötanazi meselesi, hak kavramsallaştırmasında ve kuramında ortaya konulan 'hak-ödev' ilişkisi ve 'vazgeçilmezlik' açısından ele alınacaktır.

Dahası, meselenin belli bir kuramsal çerçevede sağliklı bir şekilde tartışılabilmesi için, 'ötanazi’ kavramına ilişkin belli bir tanımsal sınırlama da yapılmalıdır. Bu tür bir tanımsal sınırlama ve tartışma, tam da çalışmanın içeriğine dahil olması nedeniyle, izleyen sayfalarda gerçekleştirilecektir.

Çalışmanın beslendiği temel kaynak, konuyla ilgili akademik literatür ve bu literatürde ortaya konulan tartışmalar üzerine gerçekleştirilen akıl yürütmedir.

Çalışma, üç başlık altında kurgulanmıştır. “"Hak' Kavramı” başlıklı birinci bölüm ile "Ötanazinin Tanımı, Niteliği ve Kapsamı" başlıklı ikinci bölümde, meselenin kavramsal ve kuramsal temeli ve bu temele ilişkin bazı tartışmalar değerlendirilecektir. "Ötanaziye İlişkin Bazı Kavramsal ve Kuramsal Zorluklar" başlıklı üçüncü bölümde ise, ötanazi-hak ilişkisi açısından bazı tartışmalı noktalara dikkat çekilecek ve böylece, bir hak olarak anlaşı1ması halinde, 'ötanazi' teriminin hak kavramı ve kuramı açısından yol açabileceği bazı sorunlara değinilecektir. "Sonuç" kısmında ise konuyla ilgili genel bir toparlama ve değerlendirme yapılacaktır. Dolayısıyla, makalenin ilk iki bölümü çalışmanın temelini oluşturmakta, 
üçüncü bölüm ise çalışmanın bu temel üzerinde yükselen gövdesini teşkil etmektedir.

\section{I. 'Hak' Kavramı}

Ötanazinin hak kavramı ve kuramı açısından nasıl değerlendirilebileceğine geçmeden önce, 'hak' kavramına ilişkin bazı noktalara değinmek gerekmektedir.

Ahlâki bir terim olarak 'hak', kendisine ahlâk alanında bazı sonuçların bağlandığı belli bir yetkiyi belirtir. Bu çalışmada temel alacağımız anlamıla, yani hukuki bir terim olarak 'hak' kavramı ise, kendisine bazı hukuki sonuçların bağlandığı belli bir yetkiyi ifade eder. ${ }^{3}$ Yetkinin içeriği hakkın konusuna göre değişmekle birlikte, bir 'hak'tan söz edilebilmesi için belli bir yetkinin varlığına ihtiyaç olduğu açıktır. Dolayısıyla, "hak hem ahlâkî hem de hukukî bir kavramdır. Her iki alanda da hak bir kişi, bir kurum veya bir şey üzerindeki gerekçelendirilmiş bir iddia veya talebi ifade eder. Hak sahibi, başka insanlar veya sosyal kurumlar tarafindan kendisine belli bir şekilde davranılmaya hakkı olduğunu ileri sürer". ${ }^{4}$ Diğer bir deyişle, bir kişinin 'belli bir hakka sahip olması' ya da '... [hakkın konusu] hakkına sahip olması'; o kişinin o konuyla ilgili belli bir iddia ya da talebe sahip olması ve bu iddiasının/talebinin gereğinin yerine getirilmesini hukuken bağlayıcı bir şekilde isteyebilmesi anlamına gelir. ${ }^{5}$

Bu bağlamda, mantığ 1 ve tanımı gereği, belli bir 'hak'kın varlığından "söz edebilmek için, o hak bağlamında şu unsurların mevcut olması gerekir: (1) Yetki: Hakkın özü bir şeyi yapabilme yetkisidir (...) Hak bu anlamda bir 'cevaz'dır. (2) Talep: Her hak, sahibine olumlu veya olumsuz bir talepte bulunma yetkisi verir. (...) bir hak başkalarına sırf bir

3 'Hak' kavramının farklı anlamları için Erdoğan, s.9-11. Hak kavramını açıklayan bazı kuramlar için Gözübüyük, s.143, 144. Hakların niteliğini açıklayan iki ana yaklaşım için Erdoğan, s.13vd. Hakların sınıflandırması için Gözübüyük, s.144vd.

${ }^{4}$ Orend'den aktaran Erdoğan, s.7.

5 Özetle, "hukuk nesnel anlamda kuralı, hak ise öznel anlamda yetkiyi anlatır. (...) Hak, bir yandan hukukun koruduğu bir çıkarı anlatır, diğer yandan da sahibine bu korumdan yararlanma yetkisini verir" (Gözübüyük, s.4, 143). 
kaçınma yükümlülüğü yükleyebileceği gibi, bir edim veya yerine getirme yükümlülüğü de yükleyebilir. (3) Saygı Gösterilme Sorumluluğu: Bir hak iddiası, hakkın konusundan yararlanma yetkisinin genel veya bir ilişkiye bağlı (özel) olarak tanınmasını istemek, ona saygı gösterilmesini meşru olarak beklemek demektir. Böyle bir meşru beklentinin varlığı talebin meşruluğunun başkaları tarafindan kabul edildiğini varsayar". 6

Diğer bir deyişle, içeriği konusuna göre farklılık göstermekle birlikte, 'hak', yetki-talep-sayg1 gösterilme sorumluluğu (talebin olumlu bir şekilde cevaplanması) olmak üzere üç unsurdan oluşmaktadır. Burada dikkat edilmesi gereken nokta şudur: Bir haktan söz edilebilmesi için her ne kadar bu üç unsur aynı ölçüde gerekli ise de, hakkın pratikte anlamlı ve kullanılabilir olabilmesi için üçüncü unsurun özel bir önem taşıdığ 1 açıktır. 'Talebin olumlu bir şekilde cevaplanması'na götüren ve literatürde 'ödev' olarak kavramsallaştırılan şey, aslında tam da bu üçüncü unsurun sonucudur.

\section{A. Hak-Ödev İlişkisi}

Yukarıda ortaya konulan 'hak' tanımının gerektirdiği mantıksal sonuçlardan biri, 'hak iddiası'nın ya da genel olarak 'hak' kavramının belli bir 'ödev' de içermesidir. Buna göre, ödev, "hakkın sınırlandırılması sonucunda oluşan hukuki durumdur".?

Gerçekten de, "hak iddiaları çok güçlü iddialardır. Bir hakka sahip olmak, yerine getirilmesinde kişinin 1srar edebileceği ve izlenmesi başkalarına yükümlülükler yükleyen bir hakka/yetkiye sahip olmaktır".

Dolayısıyla, hak-ödev ilişkisi, 'hak'kın tanımı gereği kurulan bir ilişkidir. Bu bağlamda, hak ve ödevi bir madalyonun iki yüzü olarak değerlendirmek mümkün gözükmektedir: "Haklarla yükümlülükler veya ödevler arasında genellikle bir simetri vardır. Kural olarak, her hak bir ödeve tekabül eder; bir yerde hak sahibi varsa onun karşısında ödevli

${ }^{6}$ Erdoğan, s.11, 12.

${ }^{7}$ Akıllığlu, s.13.

${ }^{8}$ Kukathas'tan aktaran Erdoğan, s.8. 
veya ödevliler vardır. Bu ödevler söz konusu olan hakkın niteliğine göre, negatif veya pozitif nitelikte olabilirler".

Buradan da anlaşılabileceği gibi, her hak belli bir ödev içerse de, bu ödevin mutlaka pozitif bir ödev olması gerekmemektedir. Gerçekten de, örneğin temel insan 'hak'ları arasında yer alan 'ifade özgürlüğü' düşünüldüğünde, bu hak karşısında üçüncü bir kişinin ya da devletin ödevinin pozitif değil de negatif bir ödev olduğu söylenebilir. Zira kişi ifade özgürlügünü kullanırken ya da kullandıktan sonra kendisine müdahale edilmemesi yeterli olacaktır; kişinin ifade özgürlüğünü fiilen kullanıp kullanmaması kişinin kendisine bırakılmakta, kişinin bu özgürlüğü kullanırken ona müdahale edilmemesi ya da kullandıktan sonra düşünceleri/ifadeleri nedeniyle cezalandırılmaması (örn. hapse atılmaması), 'hak'kın tam olarak kullanılması ve tanımlanması için yeterli olmaktadır.

Ancak, tanımı gereği pozitif bir ödev gerektiren bazı haklar da bulunmaktadır. Örneğin, 'sosyal güvenlik hakkı' söz konusu olduğunda, kişinin bu haktan faydalanması için devletin gerekli düzenlemeleri yapmış olması, ilgili kişilerin bu hakkı fiilen kullanmalarını sağlayacak önlemleri ve yöntemleri öngörmüş olması gerekir. Her hâlükârda, ister pozitif isterse de negatif olsun, bir 'hak'tan söz edilebilmesi için belli bir ödevden söz edilmesi gerektiği açıktır. ${ }^{10}$

Öyleyse, hak-ödev ilişkisinin nasıl kurulduğu, hangi unsurlardan oluştuğu ve bunun mantıksal sonucu kısaca şu şekilde özetlenebilir: "Haklar, özel bir gücün taleplerine temel olan isimlerdir. (...) hak, haksahibi ile ödevli (duty-bearer) arasındaki ilişkiyi, bu ilişki hakka dayandığı ölçüde, belirlemektedir. (...) hakların karşılığı olan ödevler hak-sahibine 'aittir', hak-sahibi bu ödevlere büyük ölçüde kendi takdirine göre, serbestçe tasarruf eder. (...) '(A)'nın (B ile ilgili olarak) (X)'e hakkı vardır' önermesi bir hak-sahibini (A), bir hak objesini (X) ve bir ödevliyi

\footnotetext{
${ }^{9}$ Erdoğan, s.15. Benzer yönde Mcconnell, s. 40.

10 "Hak sahipleri kendilerine başka birinin ödevi üstünde kontrol imkânı verilen özneler durumunda olduklarından (...)” (Erdoğan, s.13).
} 
(B) işaret eder. $\mathrm{Bu}$ önerme ayrıca söz konusu unsurların, bir hakkın sonucu olmak bakımından nasıl bir ilişki içinde bulunduklarını da gösterir: (A) (B ile ilgili olarak) (X)'e yetkilidir; (B) (A)'ya karşı (x'le ilgili olarak) mukabil bir yükümlülük altındadır; nihayet (A), bu yükümlülüklerin yerine getirilmesi konusunda (B)'den taleplerde bulunabilmelidir". ${ }^{11}$

O halde, hukuken tanınmış bir hak bakımından, ilke itibariyle, üç unsurun söz konusu olması gerektiği kabul edilebilir: (A) (hak sahibi), (B) (ödevli kişi), (X) (hakkın konusunu oluşturan şey). Böylece, örneğin, 'hak' olarak düşünülen bir 'ötanazi'den bahsedilecek ise, 'hak' kavramının tanımı gereği, bu tür bir 'ötanazi' durumunda da (A), (B) ve $(\mathrm{X})$ 'in neler olabileceğini düşünmek gerekmektedir. ${ }^{12}$

Özetle, 'hak' denildiğinde, kavramın tanımı ve anlamı gereği, belli bir ödev ilişkisi de tanımlanmış olmaktadır. Dolayısıyla, bir 'hak'tan bahsedildiğinde, negatif ya da pozitif bir 'ödev'den de bahsedilmesi gerekecektir. Dahası, 'hak'kın yukarıda ortaya konulan tanımı nedeniyle belli bir ödev içermesi zorunluluğu bir yana, bir hak 'insan hakkı' olarak nitelendirildiğinde, o hakka başka bazı sonuçlar da bağlanmış olmaktadır. $\mathrm{Bu}$ sonuçlar arasında elinizdeki çalışmanın konusu bakımından en önemlilerinden biri ise, 'vazgeçilmezlik'tir.

\section{B. Yaşama Hakkı ve Vazgeçilmezlik}

Bilindiği gibi, hak kavramının özel bir kategorisi olarak insan hakları, insanın insan olmasından kaynaklanan haklardır. ${ }^{13}$ Gerçekten de, "her kişinin insan olmak sıfatıyla sahip olduğu genel bir ahlâkî hak olarak 'insan hakkl', insan kişisinin hak ettiği bir asgarî muamele meselesi olarak her insana borçlu olunan ve haklı gerekçeleri bulunan üstün öncelikli bir iddia olarak tanımlanabilir". ${ }^{4}$

\footnotetext{
${ }^{11}$ Donnelly, s.19, 20.

12 'Ötanazi'nin bir 'insan hakkı' olarak düşünülmesi halinde karşımıza çıkan önemli sorunlardan biri tam da bu mantıksal zorunluluktan kaynaklanmaktadır. Buna ilişkin değerlendirme izleyen satırlarda yapılmaktadır.

${ }^{13}$ Donnelly, s. 19.

${ }^{14}$ Orend'den aktaran Erdoğan, s.21.
} 
$\mathrm{Bu}$ çalışmanın konusu insan hakları ve bu hakların çeşit ve içerikleri olmadığından, burada bu konuya girilmeyecektir. ${ }^{15}$ Ancak konumuz bakımından dikkat çekilmesi gereken nokta, insan haklarının, onları diğer haklardan ayıran bazı özel niteliklere sahip olduğudur. Bu nitelikler "evrensellik", "mutlaklık", "vazgeçilmezlik", "bireysellik", "özgürlükçülük", "doğuştanlık ve toplum öncesi olma", "temel bir niteliğe sahip olma" ve "devlete karşı olma" gibi başlıklar altında özetlenebilir. ${ }^{16}$ Ötanazinin bu çalışmada öngörülen tanımı ve kapsamı nedeniyle, yani bu çalışmanın konusu bakımından, biraz daha detaylı olarak incelememiz gereken nitelik ise 'vazgeçilmezlik'tir.

İnsan haklarını diğer birçok hak kategorisinden ayıran bir nitelik olarak vazgeçilmezlik (ya da devredilmezlik), hak sahibinin, insan hakları kategorisine giren bir haktan, hiçbir koşulla ve yolla (örn. sözleşme yoluyla) vazgeçemeyeceği, o hakkı devredemeyeceği ve o haktan feragat edemeyeceği anlamına gelmektedir. ${ }^{17}$ Böylece bu nitelik, insan haklarının sadece devlete ya da üçüncü bir kişiye karşı değil ama aynı zamanda hak sahibinin kendisine karşı da korunmasını sağlamakta ${ }^{18}$, bu anlamda ve açıdan bakıldığında onların 'mutlak' bir nitelik taşıdıklarını göstermektedir. ${ }^{19}$ Akıllıŏlu'nun da belirttiği gibi, "İnsan haklarının sözleşmeye konu olması ya da bunlardan vazgeçilmesi mümkün değildir.

15 İnsan haklarının meşruluk temelleri için Erdoğan, s.29vd. İnsan haklarının nitelikleri için Akıllıŏlu, s.20vd; Erdoğan, s.83vd. İnsan haklarını diğer haklardan ayıran özel nitelikler için Donnelly, s.22vd.

${ }^{16}$ Erdoğan, s.83-91.

17 Benzer yönde Block, s.241; Wellman, s.250; Feinberg, s.111. Vazgeçilmezlik/devredilmezlik kavramı hakkında detaylı değerlendirmeler için Wellman, s.250vd; Mcconnell, s.25vd.

${ }^{18}$ Benzer yönde Feinberg, s.120, 121; Tezcan/Erdem/Sancakdar, s.168, 169; İnceoğlu, s.79.

19 "Şurası açıkça gözüküyor ki, eğer bir hak mutlak ise, vazgeçilmezdir" (McConnell, s.29). 'Yaşama hakkı'nın ortadan kaldırılmasının meşru görüldüğü bazı durumlar hatırlatılarak bu hakkın mutlaklığının bir açıdan sorgulanmasına götüren değerlendirmelerin örneği için Feinberg, s.103vd. 'Yaşama hakkı'nın ortadan kaldırılmasının meşru görüldüğü durumlar için Gölcüklü/Gözübüyük, s.162vd; Tezcan/ Erdem/Sancakdar, s. 169vd. 
(...) $\mathrm{Bu}$ doğal hukuk yaklaşımı günümüzde özellikle kişi hakları bakımından etkisini sürdürmektedir". ${ }^{20}$

Dolayısıyla, bir hak 'insan hakk1' olarak nitelendirildiğinde ya da o kategoriye dahil edildiğinde, o hak açısından aslında çok önemli sonuçlar doğuran bir işlem gerçekleştirilmiş olmaktadır. Bu sonuçlardan biri de, hiç kuşkusuz, o hakkın vazgeçilmez ve devredilmez bir nitelik taşıdığının artık kabul edilmesi olacaktır.

Kaldı ki, çeşitli insan hakları arasında vazgeçilmezlik bakımından bir alt-sınıflandırma yapmanın mümkün olduğu kabul edilse bile, 'yaşama hakkı' söz konusu olduğunda, bu hakkın vazgeçilmez/devredilmez olduğunun ${ }^{21}$ literatürde genelde fazla itiraza uğramadığı görülmektedir. ${ }^{22}$ Literatürde genel kabul gördüğü üzere ve Çağlayan'ın da belirttiği gibi, yaşama hakkı "bir kimsenin 'insan' olmak sıfatiyle, vazgeçilmesi ve başkasına devri caiz olmıyan haklarındandır"23; özetle, "bireyin kendisine olduğu kadar topluma karşı da sorumlulukları olduğundan yola çıkılarak, yaşama hakkı, vazgeçilmez, devredilmez ve kutsal kabul edilmektedir". ${ }^{24}$

Dolayısıyla, tam da bu nedenlerle, 'yaşama hakkı'nın vazgeçilmez/devredilmez niteliğini doğrudan etkileyebilecek 'ötanazi' gibi bir talep söz konusu olduğunda, bu talebi bir 'insan hakkı' olarak tanımak, anlamak ve anlamlandırmak önemli sorunlara yol açabilecektir. Gerçekten de, yukarıda da ortaya konulduğu gibi, bilhassa 'yaşama hakkı' gibi bir hakk1 nitelendirmekte kullanılan vazgeçilmezlik/devredilmezlik özelliği, o hakka önemli bir güç

${ }^{20}$ Akıllığlu, s.40.

21 'Yaşama hakkı'nın vazgeçilmezliğini/devredilmezliğini temellendiren bazı gerekçeler için Wellman, s.255vd.

22 "Kişi hakları bağlamındaki temel haklar ve kişilik hakları bakımından vazgeçme yasağı mutlak bir anlam taşır. Başka bir anlatımla yaşama hakkı, insan onuru, saygınlığg gibi kişi haklarından veya kişilikle sıkıca bağlı haklardan önce ya da sonra vazgeçilmesi/feragat edilmesi mümkün veya geçerli değildir" (Akıllığlu, s.42).

${ }^{23}$ Çağlayan, s.3.

24 İnceoğlu, s.69. 'Yaşama hakkı'na ilişkin ek bilgi ve değerlendirmeler için Sudre, s.259vd; Gölcüklü/Gözübüyük, s.155vd. 
kazandırmakta, ona 'mutlak' bir nitelik vermektedir. Dolayısıyla, bir 'insan hakkı' olarak anlaşılması halinde yaşama hakkının vazgeçilmezlik/devredilmezlik özelliğiyle çelişkiye düşmesi kaçınılmaz olan 'ötanazi'nin, bu anlamda ve bu bakımdan, kavramsal ve kuramsal anlamda önemli sorunlara yol açtığ 1 söylenebilir. Ancak bu tartışmaya geçmeden önce, bu çalışmada kullanılan 'ötanazi' kavramının tanımı, niteliği ve kapsamı üzerinde kısaca durmak gerekmektedir.

\section{II. Ötanazinin Tanımı, Niteliği ve Kapsamı}

Türk Dil Kurumu'nun hazırladığı Türkçe Sözlük’te (2005), ötanazi, çok yalın bir şekilde, "kendi ölümünü isteme hakkı" olarak tanımlanmaktadır. Dil Derneği'nin hazırladığı Türkçe Sözlük'te ise (2005), ötanazi, "1. Acı çekmeden, eziyetsiz ölüm, 2. (Onulmaz hastalık vb. gibi durumlarda) Öldürme izni verme" olarak tanımlanmaktadır. ${ }^{25}$ İlk bakışta kolay ve sorunsuz gibi gözüken bu tanımlar, "ötanazi” kavramına ilişkin çeşitli soru ve sorunlar dikkate alındığında, kavrama ilişkin birçok tartışmalı noktanın göz ardı edilmesine yol açabilmektedir. Ancak bu sorunlara geçmeden önce, 'ötanazi' kavramının basit sözlük anlamını derinleştirmek ve kavramın tanımına ilişkin nispeten daha detaylı bir analiz yapmak gerekmektedir. ${ }^{26}$

Eroğul'a göre, bir olayın ötanazi [yazarın deyişiyle 'gönüllü ölüm'] olarak nitelendirilebilmesi için şu unsurları içermesi gerekmektedir: "1) Bilinen sağaltım (tedavi) yöntemlerine göre kurtuluş umudu kalmamış bir sayrılık; 2) Sayrıya dayanılmaz gelen bir acı düzeyi; 3) Sayrının yaşamına son verilmesini açıkça istemesi; 4) Yaşama son verme eyleminin sorumlu hekimce gerçekleştirilmesi". ${ }^{27}$

${ }^{25}$ Eroğul'un dikkat çektiği gibi, ötanazi, "Yunanca kökenli bir sözcük[tür]. 'Eu-' öneki, 'iyi', 'tatlı' anlamını taşıyor. 'Thanatos' ise, ölüm demek[tir]. Dolayısıyla sözcüğü 'iyi ölüm', ‘tatlı ölüm' diye çevirmek olanaklı[dır]” (Eroğul, s.49).

${ }^{26}$ Ötanaziye ilişkin tarihsel bir değerlendirme için İnceoğlu, s.17vd.

${ }^{27}$ Eroğul, s.49. 
Diğer bir deyişle, "dar anlamda ötanazi, acılarından kurtulmak için hastanın üçüncü bir kişiden kendisini öldürmesini isteme hakkı olarak belirtilebilir". ${ }^{28}$

$\mathrm{Bu}$ bağlamda, ötanazinin çeşitleri açısından, dördüncü unsurdan kaynaklanan bir sınıflandırma yapılabilmektedir. Buna göre, yaşama son verme eylemi doktor tarafindan tedavinin kesilmesi şeklinde gerçekleşirse 'pasif', doktorun öldürmeye dönük eylemi örneğin zehirli iğne vurulması gibi bir yolla gerçekleşirse 'aktif' ötanazi söz konusu olmaktadır ( ${ }^{29}$ : "Pasif ötanazi genel anlamda, hastanın bir müddet daha yaşamasını sağlayan yaşam destekleyici tedaviyi sona erdirerek ölümü hızlandırmak olarak kabul edilmektedir. Aktif ötanazi ise, ani ölüme neden olan ölümcül dozda ilacı enjekte etmek olarak görülmektedir", ${ }^{30}$

$\mathrm{Bu}$ ayrımın ötanazi tartışmaları bakımından taşıdığı önem açıktır. Zira "aktif ötanazide bir hareket varken, pasif ötanazide sadece bir kaçınma olduğu ya da ölüme neden olacak olaylara bir müdahale söz konusu olmadığı için, bu ayırımın korunması [gerekir]. Diğer bir deyişle, birinde ölüme terk, diğerinde ise öldürme vardır. (...) ölümü amaçlamak ile, istenen bir sonuç olmamasına rağmen ölümün gerçekleşeceğini öngörmek arasında fark vardır. Aktif ötanazide ölüm amaçlanırken, pasif ötanazide amaçlanmamakta ve istenmemektedir, ölüm sadece öngörülmektedir". ${ }^{31}$

${ }^{28}$ Kaboğlu, s. 163.

29 Eroğul, s.49. Pasif ötanazi, 'ortötanazi' olarak da adlandırılmaktadır: "Ortötanazi (edilgen ya da pasif ötanazi) (...) birey için hekim hiçbir iyileşme olasıllğı görmediği zaman, yaşamını uzatmaya yönelik bütün tedavi işlemlerinden vazgeçme hakkı olarak belirtilebilir" (Kaboğlu, s.163).

${ }^{30}$ İnceoğlu, s. 135.

${ }^{31}$ İnceoğlu, s.141. Dolayısıyla, bu çalışmada kullanılan ‘ötanazi’ deyişi, 'aktif ötanazi’yi ifade etmektedir. Ancak bu durumda bile bazı tanım sorunlarıly karşıllaşıllabileceği unutulmamalıdır. Örneğin, İnceoğlu'nun da dikkat çektiği gibi, tedaviyi baştan vermemek ile başlamış bir tedavi sırasında yaşam destek ünitesini kapatmak herhalde aynı pasifliğe sahip eylemler olarak nitelendirilemez (İnceoğlu, s.142, 143). Çalışmanın sınırlılı̆̆ nedeniyle, burada bu tartışmaya girilmeyecek; aktif-pasif ayrımının kolay bir şekilde yapılabildiği durumlar veri kabul edilecektir. 'Öldürme' ve 'ölüme terk etme' ayrımına ilişkin dikkat çekici tartışmalar için İnceoğlu, s.146vd. 
$\mathrm{Bu}$ bağlamda, bilinci açık, gereken bütün bilgilerle donatılmış ve akli melekeleri yerinde bir kişinin belli bir tedavi yöntemini reddetme hakkının bulunduğu (yani 'pasif ötanazi' olarak nitelendirilebilecek bir hakkın varlığı), bu ret davranışı ölüme yol açabilecek olsa da, literatürde kabul edilebilmektedir. ${ }^{32}$

Benzer şekilde, bir doktorun, hastası için yararına inanmadığı bir tedaviyi uygulamama tercihinde bulunabileceği de genel olarak tartışmasız bir husustur. ${ }^{33}$

Yukarıda tanımlandığı haliyle ötanazi bağlamında yapılan bir diğer ayrım, istemli ötanazi / istem-dışı ötanazi ayrımıdır. Buna göre, "hastanın iradesinin açık bir şekilde ötanazi uygulanması yönünde olduğu durumlarda (...) buna istemli (voluntary) ötanazi denmektedir. (...) hastanın bu konudaki iradesinin hasta tarafindan dile getirilemediği, hastalığın hastanın bilincini kaybetmesine neden olduğu durumlarda veya koma, bitkisel yaşam gibi durumlarda [uygulanan ötanaziye] istem-dış1 (non-voluntary) ötanazi denmektedir". ${ }^{34}$

Nihayet, ötanazi ile intiharı da ayırmak gerekir. Her ne kadar her ikisi de hastanın bilinçli bir tercihiyle ölüme yol açıyor ise de, intiharda hasta eylemi kendisi gerçekleştirmektedir. ${ }^{35}$ Dahası, çoğu kez gözden

\footnotetext{
32 “'Ortötanazi konusunda ötanaziye göre daha ‘yumuşak’ bir tavır alınmaktadır. Böyle bir hakkın tanınması yolunda çeşitli akımlar bulunmaktadır. Bu bağlamda, modern tedavi yöntemlerinin 'yaşayan ölü'lere (iyi edilemez hastalara) uygulanmaması savunulmaktadır" (Kaboğlu, s.163). Hatta Eroğul, bu durumun 'pasif ötanazi' olarak bile tanımlanamayacağını savunmaktadır (Eroğul, s.51). McConnell’ın da dikkat çektiği gibi, "bir doktor, bir hastanın hayat kurtarıcı tedaviyi başlatmama talebini kabul ettiğinde, o kişinin yaşamına son vermemektedir. Daha ziyade, hastasının, kendisine zorla müdahale edilmemesi yönündeki dileğine uymaktadır. Bu durumda, eylemler ile ihmaller arasındaki fark önem taşımaktadır” (Mcconnell, s.58). Tartışmanın zorluğu ve çok yönlülüğü nedeniyle, yukarıda da belirtildiği gibi, bu çalışmada 'ötanazi' denildiğinde pasif ötanazi değil aktif ötanazi kastedilmektedir.

${ }^{33}$ Eroğul, s.51.

34 İnceoğlu, s.157. Çalışmanın konusu bakımından bu ayrım çok fazla önem taşımamaktadır. Bu nedenle, burada ötanazi bakımından yapılan değerlendirmelerin her iki ötanazi türü için de geçerli olduğu kabul edilebilir. Bu iki ötanazi türü hakkında detaylı bilgi için İnceoğlu, s.158vd.

${ }^{35}$ Eroğul, s.52.
} 
kaçırıldığı gibi, 'ötanazi' esasen bir talebe dayanmaktadır (ya da bu tür bir talebin karşılanmasıdır); oysa intihar, kişinin başkasına yönelttiği bir talep değil, öldürme fiilini kendi elleriyle gerçekleştirmesidir. Elbette, özellikle doktor-yardımlı intihar durumlarında ${ }^{36}$, ötanazi ile intihar arasındaki çizginin bulanıklaşabileceğini unutmamak gerekir.

$\mathrm{Bu}$ çalışmanın konusu bakımından dikkat edilmesi gereken nokta, ötanazi-hak ilişkisidir. İntiharda ise, intiharın tanımı gereği, kişinin böyle bir hakkı olup olmadığının zaten pratikte bir anlamı bulunmamaktadır; zira intihar eden kişi, ölmenin bir yolunu zaten bulmuş (ya da bulacak) ve bunu bir şekilde kendi başına zaten gerçekleştirmiş (ya da gerçekleştirecek) demektir. ${ }^{37}$

$\mathrm{Bu}$ açıklamaların ardından, biraz da ötanazi ile yaşama hakkı arasındaki ilişkiye değinmek gerekmektedir.

Yukarıda 'vazgeçilmez bir temel hak kategorisi' olarak tanımlandığ 1 haliyle 'yaşama hakkı', Wellman'ın da dikkat çektiği gibi, bir haklar-

${ }^{36}$ Örneğin, öldürücü ilacın hastaya doktor tarafından sağlanması, ama ilacı hastanın kendi irade ve eylemiyle içmesi gibi...

37 Ötanaziye daha çok benzeyen 'yardımlı intihar' meselesine, çalışmanın sınırlılığ nedeniyle, burada değinilmeyecektir. Ancak, intihar durumunda bile kişinin sadece kendisine ilişkin bir eylemde bulunup bulunmadığ 1 tartışmalıdır. Dolayısıyla, bu tür bir eylemin kişinin ödevlerine, dolayısıyla kavramın tanımı gereği başkalarının haklarına, ama bu sefer ters yönde işleyen bir mantıkla, aykırı düşüp düşmediğinin tartışılması gerektiği hatırlatılmalıdır: "Kendimi öldürdüğümde eylemimden doğrudan etkilenen tek kişinin kendim olduğu doğrudur ama etkilenen tek kişinin kendim olduğu doğru değildir. Ailem etkilenecektir, belki arkadaşlığımın belki getirdiğim paranın kaybolması yüzünden, belki bunu önlemek için yapabileceklerine dair suçluluk duygusu yüzünden, belki de bir rahatlama ve bir yükten kurtulma hissiyle. Aynı şekilde, arkadaşlar ve başka yakın akrabalar da etkilenebileceklerdir. (...) Bir kişinin kendi hayatına sahip olduğu varsayımından yola çıkarak, kişinin ölümünün başkaları üzerinde yaptığı etkileri dikkate bile almadan bir intiharın yanlışlığını gösterebilir miyiz? Bir kişinin, bir şeye sahip olsa bile, başkalarının değer verdiği bir şeyi gözünü kırpmadan harcamasının yanlış olduğu düşüncesine dayanarak bu yapılabilir. (...) Bence, yanlışlığın bir kısmı böylesi davranışların başkalarının içinde bulundukları koşullara karşı duyarsızlık anlamına gelmesi ve onları değerlendirmemesinden gelir (...) Bir kişi için değer verdiği bir şeyin bir başkası tarafından değersiz bir şey olarak görülmesi aşağılayıcıdır. Hayat belli ki insanların değer verdiği bir şeydir; bir kimsenin intihar etmesi ve bunu yaparak hayata değer vermediğini göstermesi başkalarının kaygılarına ilgisiz kalmaktır" (Nuttall, s.155, 156). 
paketi olarak görülebilir. Buna göre, bu paketin içerisinde yer alan ve konumuz bakımından dikkate alınabilecek unsurlar özetle şunlardır: 1) Kişinin devlet görevlileri başta gelmek üzere, başkaları tarafından öldürülmemesi, 2) Kişinin yaşamının başkaları tarafından tehlikeye atılmaması, 3) Kişinin, kendi yaşamını savunabilmesi ve gerekli her tür yolla koruyabilmesi (bilhassa meşru müdafaa hakkı), 4) Kişinin, ölüm tehlikesinden kurtarılmayı talep edebilmesi (devlet görevlilerine ya da ilgili diğer kişilere yüklenen pozitif ödev) ${ }^{38} \mathrm{~K}$ ısaca, "yaşama hakkı, kamu makamlarının emri ya da izni üzerine öldürülememe ve yaşama yönelik tehlike ya da risklere karşı yine kamusal otoriteler tarafından korunma hakkıdır. (...) Devlet, bir tür aktif ve pasif olmak üzere çifte mecburiyet karşısındadır". ${ }^{39}$

Öyleyse, 'yaşama hakkı' paketine dahil olan ve 'ötanazi' talebinin etkilediği unsurlar nelerdir? Her şeyden önce, yukarıda ortaya konulan birinci unsura açık bir aykırılı̆̆ın söz konusu olacağı görülmektedir. Benzer şekilde, 'ötanazi' daha geniş yorumlandığında, ikinci, üçüncü ve hatta dördüncü unsurlara aykırılık da mümkündür. Dolayısıyla, ötanazi tartışmasız bir 'insan hakkı' olarak savunulduğunda, 'yaşama hakkının vazgeçilmezliği' bir yana, bu hakkın en basit unsurları açısından bile ciddi bir kuramsal zorlukla karşılaşılabileceği açıktır. Ancak meselenin sadece 'hak-ödev ilişkisi' ve 'yaşama hakkının vazgeçilmezliği' açısından ortaya koyduğu zorluklara değinmek bile, konunun karmaşıklığını ve kuramsal açıdan yol açabileceği sıkıntıları göstermek için yeterli olacaktır.

\section{III. Ötanaziye İlişkin Bazı Kavramsal ve Kuramsal Zorluklar}

Yukarıda tanımlandığı ve açıklandığı şekliyle 'hak' kavramı bağlamında ve yaşama hakkının vazgeçilmezliği açısından bakıldığında, 'ötanazi'yi bir 'insan hakkı' olarak tanımlamak kavramsal ve kuramsal açıdan önemli bazı zorluklara yol açmaktadır. Bu zorlukları, "hak-ödev

\footnotetext{
${ }^{38}$ Wellman, s.247-249.

${ }^{39}$ Kaboğlu, s. 154.
} 
ilişkisi açısından" ve "yaşama hakkını vazgeçilmezliği açısından" olmak üzere iki başlık altında örneklemek ve incelemek mümkündür.

\section{A. Ödev Açısından}

Çalışmanın başında da ortaya konulduğu gibi, bir talebi 'hak' olarak nitelendirmek, onun başkaları açısından belli bir ödev içermesi anlamına da gelmektedir. Zira 'bir şeyi 'hak (yetki)' olarak ileri süremediği müddetçe -yani, nihaî olarak hakka dayanma durumları var olmadıkçakişi bir faydadan yararlanabilir, ama bir hakka sahip olmaz (...) Bir hakkın gerçek değeri; hakkın konusundan yararlanmanın tehlikede olması veya inkâr edilmesi durumunda, kişiye hak taleplerini ileri sürme özel yetkisini vermesinde yatar". ${ }^{40}$

Öyleyse, aktif ötanazi hakkına sahip olduğunu iddia eden bir kişinin öldürülme talebinin yukarıda ortaya konulduğu anlamda 'hak'ka ilişkin bir talep olarak nitelendirilebileceği kabul edilirse, bu talebi yerine getirmekten kaçınmak isteyen bir doktora (yani yukarıda 'hak' kavramının unsurları açıklanırken 'B' olarak kodlanan 'ödevli’ye) aksi yönde bir ödev yüklemek gerekecektir. ${ }^{41}$ Dolayısıyla, kişinin kendisinin öldürülmesini istemesi bir 'hak' olarak kabul edilirse, bunun doğuracağ 1 mantıksal 'ödev', herhangi bir doktorun o kişiyi öldürmek zorunda kalmasına yol açacaktır. Oysa, içinde bulunduğu durumun çok ağır ve acı verici olduğunu düşünen bir kimsenin kendisini öldürmeyi ya da öldürülmeyi istemesinin ahlaken savunulabilir olduğu kabul edilse bile, başkasının bu kimseyi öldürmeye zorlanabileceğini aynı gerekçeye dayanarak savunmak mümkün gözükmemektedir. Bu durumda, Hipokrat Yemini gereği hastaları yaşatmakla sorumlu olduğunu düşünen ${ }^{42}$ bir doktorun aktif ötanazi talep eden hastayı öldürmeyi kabul etmemesi, ve

\footnotetext{
${ }^{40}$ Donnelly, s.21.

41 "İnsan hakları sadece birey devlet ilişkilerinde değil, devlet dışındaki özneler arası ilişkilerde de geçerlidir. Dolayısıyla, ödevli devlet olduğu kadar öteki özneler de olabilir" (Akıllığlu, s.14).

42 "Hipokrat Yemini de pasif ve aktif ötanazi ayrımının yapılmasına izin vermektedir. Hipokrat Yemini hekimlerin hastalarına ölümcül ilaç vermelerini açıkça yasaklarken (...)" (İnceoğlu, s.137).
} 
bütün doktorların aynı şekilde davranması, sadece kuramsal açıdan düşünüldüğünde, mümkündür. ${ }^{43}$ Öyleyse, yukarıda açıklanan hak-ödev ilişkisi gereğince, aktif ötanazinin bir 'hak' olarak savunulması, 'ödev' açısından karşılaştığı bu önemli kuramsal engel nedeniyle, kolay gözükmemektedir. ${ }^{44}$

Basitmiş gibi gözüken bu saptama, hak kavramı ve kuramı açısından genelleştirildiğinde ve düşünüldüğünde, 'aktif ötanazinin hak olarak kabul edilmesinin' önünde çok önemli ve kuvvetli bir engel oluşturmaktadır. Zira 'aktif ötanazi'; ifade özgürlüğü gibi hakların içerdiği taleplerden farklı olarak, devletin ya da üçüncü kişilerin sadece eylemsizliğinin (yani negatif ödevin) yeterli olmadı̆̆ bir talep biçimine dayanmaktadır. $\mathrm{Bu}$ tür bir ötanazinin fiilen tamamlanması ve gerçekleştirilmesi için, negatif bir ödevin (doktorun devlet tarafindan cezalandırılmaması gibi) yanı sıra, pozitif bir ödevin (fiilen öldürme zorunluluğunun) mevcudiyeti de gerekmektedir. Oysa doktorun bu tür bir talebi yerine getirmeme hakkının bulunduğu kabul edilirse (ki kabul edilebilir), aktif ötanazinin kuramsal düzeydeki ödev unsuru ortadan kalkmakta, ve böylece bu tür bir talebin değil bir insan hakk1, normal bir 'hak' olarak savunulması bile mantıksal açıdan zorlaşmaktadır.

\section{B. Vazgeçilmezlik Açısından}

Ötanazinin bir insan hakkı olarak ileri sürülmesinin yol açabileceği diğer bir sorun, yaşama hakkının vazgeçilmezliği açısından karşımıza çıkmaktadır. Zira bu durumda, temel bir insan hakkı olan yaşama hakkının vazgeçilmezliği ilkesiyle çelişkiye düşmek kaçınılmaz gözükmektedir: "İnsan haklarının devredilmez ve vazgeçilmez niteliği ile insan haysiyeti, insanın maddi ve manevi varlığı gibi yüksek değer

${ }^{43}$ Pratikte böyle bir durumun genelde gerçekleşmemesi, kuramsal tartışmayı ve burada dikkat çekmeye çalıştı̆̆ım kavramsal-kuramsal sorunu ortadan kaldırmaz.

${ }^{44}$ Nitekim, belli koşullar çerçevesinde ötanaziyi bir hak olarak düşünen Eroğul'un da dikkat çektiği gibi, "bireysel olarak her hekimin, koşullar ne olursa olsun gönüllü ölümde görev almama hakk[1] da koru[nmalıdır]. Unutulmamalıdır ki, sayrıların belli koşullarda ölümü isteme hakları bulunacaksa, hekimlerin de kendi duyunçlarına (vicdanlarına) sığmayan uygulamalardan kaçınma hakları tanınmalıdır” (Eroğul, s.54). 
kavramlarının bazı konularda çatışma ve çelişme içine girdikleri söylenebilir. (...) ölümcül hastaların durumu, yaşamına kendi isteğiyle son verme gibi sorunlar bu bağlamdadır". ${ }^{45}$

Ötanazinin istemli ya da istem-dışı olması da bu sonucu değiştirmemektedir: "Eğer yaşama hakkı vazgeçilmez/devredilmez ise, istemli ve istem-dışı ötanazi arasında ahlaki açıdan anlamlı bir fark bulunmayacaktır. (...) Ancak, istemli ve istem-dışı ötanazi arasındaki fark, rızanın bütünüyle ilgisiz olmadığını göstermektedir. (...) Öyleyse, vazgeçilmez/devredilmez bir hakkın ayırt edici özelliği, o hakkın ihlal edilmesini haklılaştırmak için hak sahibinin rızasının tek başına yeterli olmamasidır". ${ }^{46}$

Gerçekten de, Wellman'ın da dikkat çektiği gibi, "eğer hastanın yaşama hakkı vazgeçilmez/devredilmez ise, bu hasta, kendi adına ölümkalım kararları verme yetkisini başkasına nasıl verebilir? (...) Öyle gözüküyor ki, burada bir ikilemle karşı karşıya kalırız. Ya insanların (...) vazgeçilmez bir yaşama hakkı yoktur, ya da [bu tür bir devir] (...) gayrı meşrudur". ${ }^{47}$

Dolayısıyla, 'vazgeçilmez' bir hakkın konusunu ve hatta, mevcut durumda, hak sahibinin kendisini (yani yukarıda 'hak' kavramının unsurları açıklanırken 'A' olarak kodlanan 'hak-sahibi'ni!) ortadan kaldırmaya yol açan bir talebi 'hak' olarak görmek, tam da bu 'hak' tanımı ve 'vazgeçilmezlik' özelliği nedeniyle, kolay değildir.

$\mathrm{Bu}$ sorunlar karşısında, bazı dikkat çekici kuramsal akıl yürütmeler ve 'dar anlamda yaşama hakkı / geniş anlamda yaşama hakkı', 'dar anlamda vazgeçme / geniş anlamda vazgeçme' gibi ayrımlarla çeşitli çözüm yolları arandığı da görülmektedir. Örneğin Wellman, 'feragat/terk etme' ile 'vazgeçme/devretme' arasında kavramsal bir ayrım yapmakta ${ }^{48}$ ve tedaviyi reddetme sonucunu doğuran ötanazide (yani pasif ötanazide)

\footnotetext{
${ }^{45}$ Ak1llığlu, s.41, 42.

${ }^{46}$ Mcconnell, s.32.

${ }^{47}$ Welllman, s.245. Benzer yönde Feinberg, s.93, 118.

${ }^{48}$ Hakların kaybedilmesi ve hakkı sona erdiren eylem ve işlemler hakkında genel bilgi için Gözübüyük, s.158vd.
} 
yapılan şeyin 'vazgeçme/devretme' değil de 'feragat etme / terk etme' ya da 'yetkilendirme' olarak kabul edilebileceğini savunmaktadır. ${ }^{49}$ Böylece Wellman'a göre, yaşamayı tercih etmemek yaşama hakkından vazgeçildiği ya da bu hakkın devredildiği anlamına gelmemektedir ${ }^{50}$; ona göre, 'ötanaziyi seçmek ve bu yolla ölmek', yaşama hakkından vazgeçmek değil, aksine, bu hakkı aslında tam bir özgürlükle kullanmak olarak değerlendirilebilecektir. ${ }^{51}$

Benzer şekilde, Feinberg de bir haktan vazgeçmek ile o hakkın konusunu oluşturan şeyden feragat etmek arasındaki ayrıma dikkat çekmektedir. Buna göre, örneğin bir malı bağışlamak mülkiyet hakkının kendisinden vazgeçmek değil, sadece $o$ malın mülkiyetinden feragat etmektir; yani bu tür bir işlem, mülkiyet hakkını kullanmanın yollarından biri olarak düşünülebilir. ${ }^{52}$ Benzer şekilde, yaşamak yerine yaşamamayı

\footnotetext{
49 Benzer bir çözüm arayışı için Feinberg, s.94. Bu ayrımın aslında fazla bir anlam taşımadığını gösteren bir yaklaşım için Mcconnell, s.25vd. Kaldı ki, bu çalışmada 'aktif ötanazi'ye ilişkin bazı sorunlara değinilmeye çalışıldığına dikkat edilmelidir; dolayısıyla, pasif ötanaziyi temellendirebilen bu ayrım, elinizdeki çalışmanın konusu bakımından fazla bir önem taşımamaktadır.

${ }^{50}$ Wellman bu argümanı 'otobüste yer verme' örneğini kullanarak temellendirmektedir. Wellman'a göre, otobüste bir kişiye yer verdiğimizde, oturma hakkımızdan vazgeçmiş oluruz; zira o yerden kalktığımızda başka birisi o yere oturur ve dolayısıyla bizim yerimize geçmiş olur. Oysa tedavinin kesilmesini talep ettiğimizde, otobüste olduğunun aksine, başkasını bizim yerimize oturtmuş olmayız (ve zaten öyle bir şey de söz konusu olamaz); sadece, tedavi görme hakkımızı kullanmamış oluruz (Wellman, s.256). Dolayısıyla, Wellman açısından bakıldığında, 'tedaviyi reddetme hakkı' anlamında bir ‘ötanazi’yi yaşama hakkının vazgeçilmezliğiyle/devredilmezliğiyle çelişkiye düşmeden savunmak mümkün olmaktadır. Kaldı ki, 'tedaviyi reddetme' şeklinde karşımıza çıkan bu tür bir talebi, 'özel hayata müdahale edilmemesi' hakkıyla savunmak da, yine Wellman'ın dikkat çektiği gibi, mümkün gözükmektedir (Wellman, s.260).

${ }^{51}$ Wellman, s.246, 262vd. Ancak bu tür bir ayrımda bile, 'yaşama hakkı' paketine dahil olan ikinci unsur, yani 'kişinin yaşamının başkaları tarafından tehlikeye atılmaması' unsuru açısından bakıldığında, özellikle 'aktif ötanazi'nin çeşitli sorunlara yol açabileceği söylenebilir (Wellman, s.263). Wellman bu durumda 'yaşamın niteliğini öne çıkaran' yaklaşımları (bkz. İnceoğlu, s.83vd.) hatırlatan bir yorum yaparak, 'kişinin esenliği' kavramının sadece fizik ya da zihin sağlığından ibaret olmadığına dikkat çekmektedir (Wellman, s.265). Dolayısıyla, bu ikinci unsur açısından bakıldığında, 'yaşamın tehlikeye atılması' ifadesinden ne anlaşılması gerektiği önem taşıyacaktır.

${ }^{52}$ Feinberg, s. 115.
} 
seçmek de yaşama hakkından vazgeçmek olarak değil, yaşamın kendisinden feragat etmek olarak değerlendirilebilir. ${ }^{53}$

Ancak her ne kadar bu çabalar belli bir çözüm yönünde atılmış dikkate değer adımlar olarak görülebilirse de, 'hak' kavramı çalışmanın ilk bölümünde kavramsallaştırıldığı şekilde kavramsallaştırıldığı ve 'yaşama hakkı'nın vazgeçilmezliğinden 'vazgeçilemediği' sürece, ötanaziyi bir 'insan hakkı' olarak tanımlamanın önemli kavramsal ve kuramsal zorluklara yol açması kaçınılmaz gözükmektedir. ${ }^{54}$

Dahas1, 'vazgeçilmezlik' ve 'ödev' sorunu çözülmüş olsa bile, ötanaziyi bir hak olarak kullanmak isteyen kişinin iradesinin sağlıklı olup olmadığı meselesi de ayrı bir güçlüğe yol açmaktadır: "Kişi hayat hakkından vazgeçme hakkına gerçekten sahip midir? Eğer öyleyse, bu, belki de en temel özel hakkın, ilke olarak, vazgeçilebilir olduğu anlamına gelir. Aslında, acılı ve ölümcül hastalıklarla ilgili birçok durum vardır ki, orada hastanın kendi hayatına son vermeyi tercih etmesinin hukuken imkânsız olması onun haklarının ilgası anlamına gelir. Esasen, kişinin yaşamaya devam edip etmeyeceğine karar vermesine izin vermek, onu tercihler yapabilen rasyonel ahlâkî bir özne olarak görmek demektir. Elbette, böyle bir karar verdiği zaman kişinin rasyonel bir özne olduğunun ve kararının sonuçlarının bütünüyle farkında olduğunun gösterilmesi zorunludur". ${ }^{55}$

Diğer bir deyişle, bilgiye dayanan ve rasyonel bir tercihin söz konusu olmadığı durumlarda ötanazi talebini bir hak olarak savunmak

\footnotetext{
53 Ancak yine Feinberg'in dikkat çektiği gibi, 'yaşama hakkı'nın konusunun 'yaşam' olması nedeniyle, bu hakkın konusunu oluşturan şeyden bir kez feragat edildiğinde hakkın kendisinden vazgeçmek de kaçınılmazdır; zira yaşam bir kez kaybedildiğinde yeniden elde edilemez (Feinberg, s.117). Feinberg, 'yaşama hakkı'nın kendine özgü bu niteliğinin bu tür bir ayrımı fazla etkilemediğini belirtse de, bu hususu göz ardı ederek 'ötanazi'nin yaşama hakkının vazgeçilmezliğine aykırı düşmediğini savunmak zordur.

${ }^{54}$ Hakların vazgeçilmezliği/devredilmezliği üzerindeki bütün sınırlamaların kaldırılmasını ve 'vazgeçilmez/devredilmez haklar doktrini'nin terk edilmesini öneren nispeten marjinal bir yaklaşım için Block, s.252.

${ }^{55}$ Barry'den aktaran Erdoğan: s.85, 86.
} 
zaten mümkün değildirr" ${ }^{56}$ ve dahas1, burada, 'bilgiye dayanan' / 'rasyonel' gibi ifadelerin ne anlama geldiği de belirsizdir. ${ }^{57}$ Üstelik, İnceoğlu'nun da belirttiği gibi, "ötanazi, bakımsızlık yüzünden ölmek isteyenlerin başvurduğu bir yöntem değildir. (...) imkânların sınırlı olduğu Türkiye gibi ülkelerde (...) aktif ötanazinin, kişisel özerklik hakkının bir parçası olmaktan çok, maddi ve teknik yetersizliklerden dolayı zorunlu bir seçim haline gelme ihtimali yüksektir. (...) yaşam kalitesinin kötü olduğu durumlarda ötanazi uygulanması olağan bir durum, hatta bir mecburiyet haline gelebilecek, özerklik hakkından uzaklaşılacaktır". ${ }^{58}$

\footnotetext{
${ }^{56}$ Wellman, s.266. "Sadece ve sadece yaşamın vazgeçilmez olduğunu, ihtiyari bir hak olan yaşama hakkının vazgeçilebilir bir hak olduğunu savunan (...) yaklaşıma göre, özgür ve özerk bir kimse bütün haklarından vazgeçebilir ya da feragat edebilir - ama yalnızca şu şartla: tercihinin tam bilgiye dayanması, iyi düşünülmüs olması ve zorlamayla gerçekleşmemesi, yani, tamamen gönüllü olması şartıyla" (Feinberg, s.123). Görüldüğü gibi, diğer uçta yer alan görüş açısından bile, ötanaziyi kayıtsız şartsız bir hak olarak temellendirmek mümkün değildir.

${ }^{57}$ Ayrıca, kişinin yaşama hakkını kendi eliyle bizzat ortadan kaldırmasını ifade eden ve dolayısıyla bu anlamda hak kavramı açısından ve ötanaziye nazaran daha az sorunlu olarak görülebilecek intihar bağlamında bile 'rasyonel' bir tercihten bahsedilemeyeceğini savunanlar bulunmaktadır (Clarke, s.457vd). Zira burada, 'yaşama hakkı' açısından tehlikeye atılan şeyin kelimenin tam anlamıyla 'yaşamsal' bir önem taşıdığ1 ve bu tür bir tercihin, tercihte bulunan kişi açısından, geri dönüşü olmadığ unutulmamalıdır. Kaldı ki, intihar eğiliminin modern psikolojide hâlâ patolojik bir durum olarak tanımlandığı ve örneğin adli tıpta da böyle kabul edildiği bilinmektedir (Yalkut, s.79). İster intihar isterse de ötanazi olsun, bu tür bir tercih yapma eğiliminde olan bir kişinin fiziksel ve zihinsel durumu, içine düştüğü varoluşsal yalnızlığı ve muhtemel sosyal yalıtılmışlığ 1 göz önünde bulundurulduğunda, 'rasyonel birey' ya da 'özerk birey’ tanımının bu kişi için ne kadar geçerli olduğu sorgulanabilir (Clarke, s.458vd). Yasallaştırılmış ötanazinin 'özerklik' argümanıyla (bkz. İnceoğlu, s.103vd.) temellendirilemeyeceği, zayıf durumdaki hastaların haklarını ihlal edebileceği ve hastalar için yarardan çok zarar getirebileceği hakkında bkz. George/Finlay/Jeffrey, s.684, 685; Arıkan s.123. Hastanın çektiği acı nedeniyle 'gönüllü' hareket edemeyeceği ve dolayısıyla 'isteğe bağlı ötanazi' kavramının tanımı gereği sorunlu olduğu hakkında benzer bir yaklaşım için Campbell, s.242vd. Dolayısıyla, bu yazarların bakış açısından değerlendirildiğinde, aktif-pasif ötanazi ayrımı da anlamsız hale gelmekte ve ötanazinin kavramsal ve kuramsal bakımdan kelimenin tam anlamıyla bir 'hak' olarak temellendirilmesi mümkün gözükmemektedir.

58 İnceoğlu, s.253.
} 
Kaldı ki, bilgiye dayanan ve rasyonel bir tercihin söz konusu olduğu durumlarda bile, ötanazi talebini bir hak olarak savunmanın kolay olmadığı ve 'yaşama hakkının vazgeçilmezliği' ile 'hak-ödev ilişkisi' açısından çeşitli sorunlar içerdiği yukarıda kısaca açılanmıştır. McConnell'ın belirttiği gibi, "eğer bir hak vazgeçilmez/devredilmez ise, o hakkın sahipliğinden feragat edilemez ya da o sahiplik başkasına devredilemez. (...) Eğer yaşama hakkı vazgeçilmez/devredilmez ise, sadece birisi rıza gösterdi diye o kişinin yaşama hakkını elinden almak mümkün değildir. Yaşama hakkının sahibi olan kişinin kendini öldürüp öldüremeyeceği ise ayrı bir meseledir ve yaşama hakkının vazgeçilmez/devredilmez bir statüye sahip olup olmadığıyla belirlenmez". 59

Özetle, 'ötanazi’yi bir hak olarak kavramsallaştırmak birçok açıdan önemli zorluklarla karşılaşmak anlamına gelmektedir. Yaşama hakkı vazgeçilmez/devredilmez bir hak olarak tanımlanıyor ise, bu hakkı ortadan kaldırma yetkisinin kişinin kendisine bırakılabileceğini savunmak kolay gözükmemektedir; dolayısıyla, kişinin kendisine bile bırakılamayan bu tür bir yetkinin başkasina verilebileceğinin savunulması daha da zor olacaktır. ${ }^{60}$ Ve ayrıca, 'hak' kavramının bir ödev unsuru gerektirdiği de unutulmamalıdır. Oysa yukarıda da ortaya konulduğu gibi, bir kişiye böyle bir öldürme ödevinin dayatılabilmesi hem kavramsal, hem kuramsal, hem ahlaki, hem de hukuki açıdan imkânsız gözükmektedir. ${ }^{61}$ O halde, intihara ilişkin tartışmalar bir yana ${ }^{62}$, (aktif) ötanaziyi kavramsal ve kuramsal açıdan temellendirilebilir bir 'hak' olarak savunmak bu nedenle de kolay değildir.

\section{Sonuç}

$\mathrm{Bu}$ çalışmada, '(aktif) ötanazi'yi bir 'insan hakkı' olarak nitelendirmenin ve tanımlamanın, 'hak kavramı ve kuramı' ile 'yaşama

\footnotetext{
${ }^{59}$ Mcconnell, s.43.

${ }^{60}$ Benzer yönde bir dikkat çekme için Mcconnell, s.43.

${ }^{61}$ Kişinin öldürülme talebinin hiçbir doktor tarafından kabul edilmediği bir durumun en azından kuramsal açıdan mümkün olduğu yukarıda belirtilmişti.

${ }^{62}$ İntihara ilişkin muhtemel sorunsalların bu çalışmada ele alınmadığı hatırlatılmalıdır.
} 
hakkının vazgeçilmezliği' açısından bazı önemli sorunlara yol açtı̆̆ gösterilmeye çalışılmıştır. Elbette, konu çok kapsamlıdır ve daha detaylı açıklamalar, inceleme ve değerlendirmeler gerektirmektedir.

$\mathrm{Bu}$ çalışmada asıl yapılmak istenen şey, meselenin ilk başta zannedileceği kadar kolay olmadığını göstermek ve konuyla ilgili tanım ve adlandırmalarda dikkatli olmak gerektiğini vurgulamaktır. Zira yukarıda kısaca ortaya konulduğu gibi, meselenin çeşitli yönleri üzerine fazla düşünmeden ötanaziyi hemen bir 'hak', hatta bir 'insan hakkı' olarak tanımlamak önemli kavramsal ve kuramsal sıkıntılara yol açabilmektedir.

$\mathrm{Bu}$ bağlamda, her şeyden önce, 'hak' kavramının tanımı gereği içerdiği unsurların göz ardı edilmemesi gerekmektedir. Kavramsal ve kuramsal açıdan bakıldığında 'hak' kavramının ayrılmaz bir parçası olan 'ödev' unsuru, ötanazinin bir 'hak' olarak tanımlanması söz konusu olduğunda, önemli bir zorluğa yol açmaktadır. Buna göre, ötanazi talep eden bir kişinin bu talebine olumlu yanıt vererek onu öldürmeyi kabul edecek başka bir kişinin bulunmaması halinde, bu talebin 'ödev' zincirinin kopması hem kuramsal açıdan hem de -çok düşük bir ihtimal de olsa- pratik açıdan mümkündür. $\mathrm{Bu}$ ise, ötanaziyi bir hak olarak kavramsallaştırmayı kuramsal açıdan zorlaştırmaktadır.

Ötanazinin bir hak olarak tanımlanmasıyla yetinilmeyerek onun bir 'insan hakkı' olarak tanımlanması halinde ise, ek bir güçlükle, yani yaşama hakkının 'vazgeçilmezliği/devredilmezliği'yle ötanazinin nasıl bağdaştırılabileceği meselesiyle karşılaşılmaktadır. Bu konuda çeşitli kavramsal ayrımlara (aktif ötanazi / pasif ötanazi ayrımı, istemli ötanazi / istem-dışı ötanazi ayrımı, hakkın kendisinden vazgeçme / hakkın konusunu oluşturan şeyden feragat etme ayrımı gibi) dayandırılan bazı çözüm yolları sunulmuş ise de, bu önerilerin sorunu tam olarak çözebilmesi mümkün gözükmemektedir.

Özetle, 'yaşam' ve 'ölüm' gibi insan varoluşunun iki temel eşiğinin söz konusu olduğu bir durumda, meselenin 'hak' ya da belki de daha ikna edici bir ifadeyle 'insan hakkı' kavramlarına başvurularak bile çözülmesi 
kolay değildir. Nihayetinde mesele, gerçekten de, bir 'ölüm-kalım' meselesidir. Şu halde, ötanazi gibi zor bir konu üzerine kesin sonuçlara varmadan önce, meselenin kavramsal ve kuramsal boyutları ve sonuçları üzerine daha fazla inceleme, değerlendirme ve analizler yapmak, çok yönlü sorgulamalarda bulunmak gerekmektedir. Okuduğunuz çalışma, işte bu yönde atılan adımların sadece küçük bir halkasını oluşturmaktadır. 


\section{KAYNAKÇA}

Ak1llığlu, Tekin. (1995). Insan Haklart -I- Kavram, Kaynaklar ve Koruma Sistemleri. Ankara: A.Ü. S.B.F. İnsan Hakları Merkezi Yay.

Arıkan, Baha. (1954). Ötanezi. Adalet Dergisi, 1, 119-123.

Biggs, Hazel. (2001). Euthanasia, Death with Dignity and the Law. Oxford: Hart Pub.

Block, Walter. (2006). Epstein on Alienation: A Rejoinder. International Journal of Social Economics, 33(3), 241-260.

Brassington, I. (2006). What Kant Could Have Said about Suicide and Euthanasia but Did Not. Journal of Medical Ethics, 32(10), 571-574.

Brogden, Mike. (2001). Geronticide: Killing the Elderly, London: Jessica Kingsley Pub.

Campbell, Neil. (1999). A Problem for the Idea of Voluntary Euthanasia. Journal of Medical Ethics, 25(3), 242-244.

Clarke, David M. (1999). Rationality and the Wish to Die. Journal of Medical Ethics, 25(6), 457-462.

Çağlayan, Muhtar. (1966). Ötanezi ve İntihar. Adalet Dergisi, 57, 3-33.

Donnelly, Jack. (1995). Teoride ve Uygulamada Evrensel Insan Haklarl. Ankara: Yetkin Yay.

Erdoğan, Mustafa. (2007). Insan Hakları Teorisi ve Hukuku. Ankara: Orion Kitabevi.

Eroğul, Cem. (1993). Ölüm Hakk1. A.Ü. Siyasal Bilgiler Fakültesi Dergisi, 48(1-4), 47-56.

Feinberg, Joel. (1978). Voluntary Euthanasia and the Inalienable Right to Life. Philosophy and Public, 7(2), 93-123.

Feyzioğlu, Metin. (1993). Açlık Grevi, A.Ü. Hukuk Fakültesi Dergisi, 43(1-4), 157-168. 
Foot, Philippa. (1977). Euthanasia. Philosophy and Public Affairs, 6(2), 85-112.

Garrard, E. / Wilkinson, S. (2005). Passive Euthanasia. Journal of Medical Ethics, 31(2), 64-68.

George, R. J. D. / Finlay, I. G. / Jeffrey, David. (2005). Legalised Euthanasia will Violate the Rights of Vulnerable Patients. British Medical Journal, 331(7518), 684-685.

Gölcüklü, A. Feyyaz. / Gözübüyük. A. Şeref. (2002). Avrupa İnsan Hakları Sözleşmesi ve Uygulaması - Avrupa Insan Hakları Mahkemesi Inceleme ve Yargllama Yöntemi. Ankara: Turhan Kitabevi Yay.

Gözübüyük, Şeref. (1995). Hukuka Giriş ve Hukukun Temel Kavramları. Ankara: Turhan Kitabevi Yay.

Griffiths, J. / Weyers, H. / Adams M. (2008). Euthanasia and Law in Europe. Oxford: Hart Pub.

Humphry, Derek. (2002). Final Exit: The Practicalities of Selfdeliverance and Assisted Suicide for the Dying (3rd ed.). New York: Dell Pub.

Huxtable, Richard. (2007). Euthanasia, Ethics and the Law: From Conflict to Compromise. New York: Routledge-Cavendish Pub.

İnceoğlu, Sibel. (1999). Ölme Hakkı: Ötanazi. İstanbul: Ayrıntı Yay.

Kaboğlu, İbrahim. (1993). Özgürlükler Hukuku. İstanbul: AFA Yay.

Kuflik, Arthur. (1986). The Utilitarian Logic of Inalienable Rights. Ethics, 97(1): 75-87.

Lavi, Shai J. (2005). The Modern Art of Dying: A History of Euthanasia in the United States. Princeton: Princeton University Press.

McConnell, Terrance. (1984). The Nature and Basis of Inalienable Rights. Law and Philosophy, 3(1): 25-59. 
McLean, Sheila A. M. (2007)., Assisted Dying: Reflections on the Need for Law Reform. New York: Routledge-Cavendish Pub.

Nuttall, Jon. (1997)., Ahlâk Üzerine Tartışmalar: Etiğe Giriş. İstanbul: Ayrıntı Yay.

Paterson, Craig. (2008). Assisted Suicide and Euthanasia: A Natural Law Ethics Approach. Ashgate e-Book: Ashgate Pub.

Sudre, Frédéric. (2003). Droit européen et international des droits de l'homme. Paris: PUF.

Terrance, McConnell. (1984). The Nature and Basis of Inalienable Rights. Law and Philosophy, 3(1), 25-59.

Tezcan, Durmuş. / Erdem, Mustafa Ruhan. / Sancakdar, Oğuz. (2002). Avrupa Insan Hakları Sözleşmesi Işı̆ğında Türkiye'nin Insan Hakları Sorunu. Ankara: Seçkin Yay.

Uslu, Cennet. (2009). Doğal Hukuk ve Doğal Haklar. Ankara: Liberte Yay.

Warnock, Mary. / Macdonald, Elisabeth. (2008). Easeful Death: Is There a Case for Assisted Dying?. New York: Oxford University Press.

Wellman, Carl. (1995). The Inalienable Right to Life and the Durable Power of Attorney. Law and Philosophy, 14(2): 245-269.

Yalkut, Necdet. (1976). Çeşitli Yönleriyle İntihar ve İntihara İştirak. Adalet Dergisi, 67, 78-85.

Young, Robert. (2007). Medically Assisted Death. New York: Cambridge University Press.

Yount, Lisa. (2007). Right to Die and Euthanasia (Rev. ed.). New York: Facts on File. 